\title{
PENDIDIKAN SENI MUSIK BERBASIS BAHAN AJAR MULTIKULTURAL
}

\author{
Ariel Januar Chrisnahanungkara \\ Universitas Negeri Semarang \\ chrisnahanungkara@ymail.com
}

\begin{abstract}
Abstrak
Melimpahnya budaya di Indonesia yang belum digarap secara maksimal menimbulkan masalah bagi Indonesia ketika mereka tidak menguasai kebudayaan itu. Pendidikan seni memiliki posisi yang strategis dalam rangka menjaga eksistensi kebudayaan di Indonesia. Penulis dalam artikel ini memaparkan bagaimana kebudayaan digarap sebagai bahan ajar pendidikan seni dalam rangka menjaga eksistensi kesenian lokal. Penulis memulai dengan menjelaskan pendidikan seni, pendidikan multikultural kemudian menghubungkan penerapan pendidikan multikultural dalam pendidikan seni musik. Pendidikan multikultural dalam penelitian ini ditempatkan sebagai bahan kajian dan mengambil kesenian lokal sebagai bahan ajar pendidikan seni musik. Penggunaan kesenian lokal sebagai bahan ajar pendidikan seni dilaksanakan dengan harapan supaya kesenian lokal tetap terpelihara.
\end{abstract}

Kata kunci: kebudayaan; pendidikan musik; multikultural

\begin{abstract}
The abundance of culture in Indonesia that has not been worked out to the maximum causes problems for Indonesia when they do not master the culture. Art education has a strategic position in order to maintain the existence of culture in Indonesia. The author in this article describes how culture is cultivated as a teaching material for art education in order to maintain the existence of local arts. The author begins by explaining art education, multicultural education then connecting the application of multicultural education in music art education. Multicultural education in this study was placed as study material and took local arts as teaching material for music art education. The use of local arts as teaching materials for art education is carried out in the hope that local art will be maintained.
\end{abstract}

Keywords: culture; art education; multicultural

\section{Pendahuluan}

Indonesia merupakan negara yang memiliki keanekaragaman budaya. Indonesia menjadi tempat tinggal bagi banyak suku bangsa dan membuat Indonesia menjadi salah satu negara yang memiliki banyak suku dan bahasa. Kondisi geografis juga menjadi potensi Indonesia sehingga menambah keanekaragaman budayanya.

Pluralitas merupakan sebuah fakta tentang kepelbagaian yang ada secara alami dan berdasarkan hukum alam: ras, warna kulit, suku, agama, budaya, dan jenis kelamin (Hanafy, 2015, p. 121). Data Badan Pusat Statistik tahun 2010 menunjukkan bahwa Indonesia memiliki sekitar 1.340 suku bangsa. Indonesia ditinggali oleh suku Jawa, Sunda, Dayak, Batak, dan suku-suku yang lainnya. Suku-suku itu tidak hanya tinggal pulau, kota atau daerah asalnya, namun juga ada yang mengalami perpindahan sehingga dapat 
ditemukan kota dengan penduduk yang berasal dari berbagai suku. Kondisi geografis dan sejarah peradaban yang dimiliki Indonesia mendukung kealamian dan kekayaan pluralitas di Indonesia.

Keanekaragaman budaya di Indonesia memiliki peluang yang sangat besar dalam mengembangkan kebudayaan yang dimilikinya. Kelemahan yang perlu diperbaiki adalah bagaimana keseriusan Indonesia dalam menggarap kebudayaannya. Indonesia dapat unggul karena memiliki kekayaan budaya dibandingkan negara lain, tetapi belum tentu unggul dalam menggarap budaya yang dimilikinya. Indonesia pernah merasakan peristiwa di mana salah satu kebudayaannya diakui oleh negara lain secara internasional. Indonesia sebagai pemilik kebudayaan merasa kehilangan tetapi tidak tahu harus berbuat apa. Peristiwa yang pernah dialami Indonesia diharapkan tidak akan terulang lagi dan menjadi pemacu untuk mengakui keberadaan budaya yang dimilikinya.

Kebudayaan adalah keseluruhan gagasan sistem gagasan, tindakan, dan hasil karya manusia dalam kehidupan masyarakat yang dijadikan milik dari manusia dengan belajar (Koentjaraningrat, 2015). Kebudayaan dilihat dari sudut pandang Koentjaraningrat bukan hanya sekedar hasil yang dimiliki oleh manusia melainkan juga menyangkut proses bagaimana manusia menghasilkan kebudayaan. Manusia sebagai makhluk berbudaya seharusnya mempelajari kebudayaan yang dimilikinya. Proses manusia dalam mempelajari kebudayaan dilakukan melalui lembaga pendidikan. Kebudayaan tidak dapat dipisahkan dengan proses pendidikan. Seni sebagai bentuk kebudayaanpun selayaknya juga tidak dapat dipisahkan dengan proses pendidikan.

Indonesia memasukkan kebudayaan sebagai bahan ajar bagi peserta didik pada tingkat dasar, menengah, hingga pendidikan tinggi. Pendidikan mengenai kebudayaan dipelajari melalui lembaga formal, informal maupun nonformal. Pendidikan mengenai kebudayaan biasa diikutsertakan dalam pendidikan seni, baik berupa seni musik, rupa, tari maupun teater.

Pendidikan seni musik di Indonesia seringkali menerapkan teori-teori musik Barat. Lembaga pendidikan kesenian nonformal seperti lembaga kursus bahkan gereja pun banyak yang mengaplikasikan teori musik Barat. Belum banyak masyarakat Indonesia mendalami musik sebagai unsur kearifan lokalnya, maka dari itu bukan hal yang aneh jika masyarakat Indonesia merasa asing dengan kebudayaannya sendiri. Ketidaksadaran masyarakat untuk mendalami kebudayaan lokal yang dimiliki akan mengancam eksistensi kebudayaannya. Warisan budaya lokal perlu diberikan kepada generasi berikutnya. 
Permasalahan yang perlu direnungkan secara mendalam dan perlu segera dijawab adalah bagaimana memaksimalkan peran pendidikan seni menjadi alat perpindahan budaya antar generasi.

Keanekaragaman budaya yang ada di Indonesia menjadi tantangan bagi pendidik seni musik. Bahan ajar dapat menjadi problem yang dialami oleh pendidik seni musik. Bahan ajar yang mendasarkan diri kepada kebudayaan lokal terkadang membuat pengajar mengalami keterbatasan dalam memahami dan mengaplikasikan bahan ajar sesuai dengan kurikulum yang sudah dibuat. Penguasaan pengetahuan yang kurang mendalam oleh pendidik mengenai kebudayaan lokal membuat pelaksanaan pendidikan musik di sekolah menjadi tidak maksimal. Sehingga perlunya keterbukaan bagi pendidik seni musik untuk berbaur dengan seniman, budayawan, maupun masyarakat lokal demi mengembangkan diri dan memahami potensi kebudayaan disekitarnya.

Keberagaman di Indonesia menghadirkan berbagai tantangan yang disesuaikan dengan wilayahnya. Pengajar pendidikan seni musik perlu memahami keberagaman yang ada serta perlu memeras pikiran untuk memecahkan problematika-problematika yang dapat muncul diakibatkan oleh keberagaman di Indonesia. Bagaimana menjadikan pendidikan seni musik sebagai sarana untuk belajar kebudayaan daerah?

\section{Pendidikan Seni di Sekolah-Sekolah Indonesia}

Pendidikan seni diajarkan kepada peserta didik dan dituangkan dalam mata pelajaran yang didapatkan oleh peserta didik di sekolah. Keberadaan pendidikan seni di sekolah formal terkadang tidak terlalu dipandang secara serius dan sering kali dijadikan sebagai mata pelajaran tambahan saja. Pendidikan seni dalam lembaga formal sering kali mendapatkan porsi yang sangat sedikit. Keterbatasan ini memunculkan ketidakmaksimalan peran pendidikan seni bagi peserta didik di sekolah.

Seni berdasarkan mediumnya diklasifikasikan ke dalam berbagai jenis yaitu seni visual, audio, verbal, dan mixed. Keberagaman jenis seni yang ada sering kali dilaksanakan dalam satu pelajaran yang sama dalam lembaga pendidikan formal. Sekolah sebagai lembaga formal dalam kurun waktu tertentu—semester maupun tahun-mempelajari seni rupa, seni musik, seni tari, dan seni drama sekaligus. Pembelajaran seperti ini membuat pendidikan seni tidak dapat dilaksanakan secara maksimal, dikarenakan fokus pelajaran yang bercabang. Pembagian waktu dalam pelaksanaan seni rupa, musik, tari maupun drama belum tentu dapat dilaksanakan dengan bobot jam pelajaran yang sama. 
Keterbatasan waktu dalam melaksanakan pelajaran seni di sekolah formal juga memberi pengaruh yang penting bagi proses pembelajarannya. Keterbatasan waktu belajar membuat pengajar dalam sekolah formal kurang maksimal bahkan dapat merasakan kebingungan ketika melaksanakan pendidikan seni musik. Bahaya yang dihadapi jika pendidikan seni memiliki waktu yang sedikit adalah munculnya anggapan bahwa pendidikan seni dilaksanakan hanya untuk pelengkap bagi mata pelajaran lain di sekolah. Pengajar sering kali memberikan pelajaran seni sebatas sebuah keterampilan agar peserta didik mampu menguasai teknik-teknik tertentu. Keterbatasan waktu membuat peserta didik kurang mendapatkan pengalaman yang mendalam mengenai kesenian.

Bahan ajar pendidikan seni musik yang dilaksanakan dalam sekolah formal maupun lembaga kursus sering kali mengadopsi ilmu yang digunakan dalam teori musik Barat. Menurut penulis, bahan ajar yang mengadopsi teori-teori dari Musik Barat bukanlah sebuah hal yang harus dihindari, karena ilmu dan istilah-istilah yang digunakan dalam musik Barat merupakan bahasa universal yang mewakili bentuk-bentuk musik di Eropa sampai sekarang. Pembelajaran seni musik berbasis bahan ajar musik Barat memberikan keuntungan kepada siswa yaitu siswa memahami musik yang secara universal dipakai dalam masyarakat dunia. Siswa mendapatkan kemampuan untuk memahami istilah-istilah yang digunakan dalam musik yang digunakan secara internasional. Siswa juga mendapat keterampilan dasar untuk memainkan instrumen musik yang digunakan secara universal.

Pendidikan seni musik di Indonesia perlu melihat potensi kebudayaan lokal yang ada. Kebudayaan lokal yang ada di sekitar perlu digarap secara serius untuk dijadikan bahan ajar dan diajarkan sehingga masyarakat mengenal serta memiliki kebudayaan yang memang seharusnya menjadi milik masyarakat tersebut. Pengenalan yang baik mengenai kebudayaan lokal akan membuat manusia dapat menjaga bahkan mengembangkan kebudayaannya. Penguasaan yang baik mengenai kebudayaannya akan membuat masyarakat pemilik kebudayaan tidak akan merasa malu ketika berkomunikasi mengenai kebudayaan-kebudayaan yang dimilikinya. Pendidikan seni musik di Indonesia diharapkan dapat memanfaatkan kebudayaan lokal sebagai bahan ajar pendidikan seni musik untuk melengkapi peserta didik mengenai pengetahuan, konsep bahkan nilai-nilai yang terkandung dalam kesenian musik lokal di sekitar peserta didik. 


\section{Peran Pendidikan Seni}

Pendidikan seni musik memiliki peran yang sangat penting dalam mengembangkan manusia. Seni musik menjadi sarana bagi manusia untuk menumbuhkan kesadaran manusia untuk menyeimbangkan diri secara intrapersonal maupun interpersonal (Desyandri, 2014). Keuntungan seni musik selayaknya perlu diperhatikan dan tidak hanya dijadikan pelengkap dalam mata pelajaran yang diajarkan di sekolah. Pendidikan yang bertumpu kepada aspek rasionalitas membuat manusia sebagai peserta didik merasa kelelahan diakibatkan oleh pemaksimalan fungsi salah satu otak manusia. Manusia yang memiliki dua bagian otak perlu menyeimbangkan bahkan memaksimalkan peran kedua otak tersebut.

Dewantara (2011, p. 303) berpendapat bahwa ilmu pengetahuan memiliki pengaruh untuk mempertajam dan mempercerdas pikiran serta memperdalam dan memperhalus budi. Pokok pikiran yang disampaikan oleh Dewantara diharapkan menjadi bahan evaluasi melihat kondisi pendidikan di Indonesia saat ini. Pendidikan di Indonesia dilaksanakan dengan harapan untuk mencerdaskan pikiran dan memperhalus budi peserta didik sehingga peserta didik memiliki watak yang baik sesuai dengan UU No 3 Tahun 2003 tentang Pendidikan Nasional pasal ketiga. Problematika yang secara keseluruhan dihadapi di banyak sekolah formal adalah pendidikan yang dilaksanakan dengan menekankan aspek kognitif.

Pemaksimalan peran pendidikan dalam mempertajam dan mencerdaskan pikiran membuat hasil luaran peserta didik hanya diukur dari sejauh mana atau seberapa tinggi peserta didik mendapatkan nilai akademik. Kondisi ini sering membuat peserta didik berlomba-lomba untuk mendapat nilai tertinggi dan sering kali menghalalkan banyak cara demi mendapat nilai yang baik. Pelaksanaan pendidikan seakan-akan tidak seimbang karena penekanan akan tingginya nilai akademik yang membuat penghalusan budi manusia kurang mendapat perhatian penuh. Pendidikan seni memiliki peran yang strategis dalam rangka memperhalus budi manusia. Seni apapun mediumnya akan membantu manusia untuk memperdalam dan memperhalus budi melalui kegiatan ekspresi, apresiasi, dan kreasi.

Dewantara (2011, p. 303) secara khusus mengatakan bahwa panca indera manusia merupakan alat penyambung dunia semesta dengan jiwa manusia. Seni menjadi sarana manusia untuk memaksimalkan penggunaan panca indera, baik indera penglihatan maupun pendengaran karena aktivitas seni memanfaatkan kepekaan panca indera. Pemanfaatan 
kepekaan panca indera membuat manusia mampu merasakan dan menghayati keindahan. Pendidikan seni musik dapat dijadikan sarana untuk mengembangkan potensi rasa keindahan dan mengembangkan kepekaan anak terhadap lingkungannya (Safrina, 2002, p. xiv).

Triyanto (2016, p. 8) memberikan pendapat bahwa pendidikan haruslah dilakukan secara manusiawi dan diorientasikan untuk memanusiakan manusia dengan segala sifatsifat kemanusiaannya itu. Manusia memiliki banyak potensi dan potensi yang dimiliki manusia perlu diasah melalui pendidikan. Potensi yang dimiliki manusia tidak hanya sebatas potensi dalam aspek rasio, namun juga memiliki potensi lain yang perlu diasah. Potensi ini berkaitan dengan kreativitas, karakter, keindahan, dan berbagai potensi yang lain. Seni menjadi sarana yang ideal demi membantu manusia untuk memaksimalkan sifat kemanusiaannya itu.

Pendapat-pendapat yang dikemukakan oleh Dewantara, Desyandri, dan Triyanto memberikan kesimpulan yang sama mengenai pentingnya pendidikan seni bagi manusia. Penulis menyimpulkan bahwa pendidikan seni perlu dilaksanakan secara terorganisir, maksimal, dan seoptimal mungkin demi mengembangkan potensi yang dimiliki oleh manusia. Pendidikan tidak sekadar penajaman aspek kecerdasan manusia, pendidikan tidak boleh melupakan tujuannya untuk memperhalus budi manusia karena pendidikan seni merupakan usaha yang dilakukan secara sadar untuk mengubah sikap dan mengembangkan potensi (Wibawa, 2017, p. 50). Pendidikan seni musik sudah sepatutnya dilaksanakan demi penyeimbang sehingga melalui seni kecerdasan, budi manusia diperhalus dan potensipotensi yang dimiliki manusia dapat dimaksimalkan untuk membentuk pribadi yang sempurna.

\section{Pendidikan Multikultural}

Pendidikan multikultural merupakan pendidikan yang dimulai di Amerika Serikat. Pendidikan multikultural merupakan sebuah gerakan reformasi sebagai protes yang dilatarbelakangi oleh diskriminasi dalam dunia pendidikan di Amerika Serikat. Gerakan pendidikan multikultural dilaksanakan dalam rangka mereformasi lembaga pendidikan di Amerika Serikat agar memberikan peluang yang sama tanpa ada batasan asal usul etnis, warna kulit serta jenis kelamin.

Mukarram dalam Irawan (2017, p. 71) berpendapat bahwa pendidikan multikultural dapat diartikan sebagai strategi untuk mengembangkan kesadaran atas kebanggaan 
seseorang terhadap bangsanya. Zamroni (2011, p. 140) memberikan pengertian bahwa pendidikan multikultural merupakan suatu bentuk reformasi pendidikan yang bertujuan untuk memberikan kesempatan yang setara bagi semua siswa tanpa memandang latar belakangnya, sehingga semua siswa dapat meningkatkan kemampuan yang secara optimal sesuai dengan ketertarikan minat dan bakat yang dimiliki. Selain itu Baidhawy (2005, p. 8) memberikan pengertian pendidikan multikultural merupakan cara untuk mengajarkan keragaman.

Bank (2002) merumuskan ada beberapa tujuan pendidikan multikultural yaitu (1) membantu individu memahami diri sendiri secara mendalam dengan mengaca diri dengan kacamata budaya lain; (2) membekali peserta didik pengetahuan mengenai etnis dan budaya-budaya lain, budaya sendiri, dan lintas budaya; (3) mengurangi derita dan diskriminasi ras, budaya maupun warna kulit. Sedangkan Desyandri (2014) menjelaskan pendidikan multikultural dilaksanakan dengan tujuan untuk membantu meningkatkan perilaku kesadaran dan kepedulian unsur-unsur pendidikan, baik itu pendidik, peserta didik, masyarakat, maupun lembaga pendidikan terhadap permasalahan kultur dan interaksi lintas kultur dalam rangka mewujudkan demokrasi dan ketidakadilan.

Pendidikan multikultural yang telah diutarakan oleh Mukarram, Zamroni, dan Baidhawy mendukung pemahaman dari Bank dan Desyandri mengenai tujuan pendidikan multikultural dimana pendidikan multikultural membekali peserta didik dengan sebuah pengetahuan dan kesadaran mengenai etnis dan budayanya. Pendidikan multikultural tidak hanya memberikan pemahaman dan kesadaran tentang kebudayaan diri sendiri, namun juga membuat sikap dan pemikiran siswa agar lebih terbuka dalam memahami dan menghargai keanekaragaman (Muslim, 2016, p. 56).

Gerakan pendidikan multikultural yang berdasar kepada reformasi yang dihadapi oleh dunia pendidikan di Amerika Serikat tidak secara mudah dapat diterapkan di Indonesia. Latar belakang pendidikan yang terjadi di Amerika Serikat dan Indonesia tentu berbeda serta perlu ada penyesuaian dalam pelaksanaan pendidikan multikultural di Indonesia.

Pendidikan multikultural dapat dilihat dan ditempatkan dalam tiga posisi yaitu sebagai falsafah pendidikan, sebagai pendekatan pendidikan dan bidang kajian serta bidang studi (Amirin, 2012, p. 6). Pendidikan multikultural dalam konteks pendidikan seni ditempatkan sebagai bidang kajian dan bidang studi dimana pendidikan seni mengkaji aspek kebudayaan dalam pelaksanaan pendidikan. Aspek kebudayaan dijadikan bahan ajar 
yang akan membuat peserta didik memahami dan menghargai kebudayaan yang ada di lingkungan peserta didik.

\section{Pendidikan Seni Musik Berbasis Bahan Ajar Multikultural}

Pendidikan seni musik merupakan suatu proses pendidikan yang membantu pengungkapan ide/ gagasan seseorang yang ditimbulkan dari gejala lingkungan dengan mempergunakan unsur-unsur musik, sehingga terbentuknya suatu karya musik yang tidak terlepas dari rasa keindahan (Retnowati, n.d.). Pendidikan seni musik bertujuan untuk memberi kesempatan kepada peserta didik untuk berekspresi, berapresiasi, berkreasi membentuk harmoni, dan menciptakan keindahan melihat kondisi yang ada di sekitarnya.

Pendidikan seni musik berbasis bahan ajar multikultural merupakan sebuah proses pendidikan seni yang mengkaji tentang aspek kebudayaan. Pendidikan seni berbahan ajar multikultural dalam konsep ini memasukkan aspek kebudayaan terutama yang berkaitan dengan musik sebagai bahan ajar dan membuat peserta didik mempelajari kebudayaan yang ada disekitarnya. Peserta didik akan mempelajari musik yang menjadi warisan budaya melalui kegiatan apresiasi, ekspresi, dan kreasi. Pelaksanaan pendidikan seni musik berbasis bahan ajar multikultural akan menolong peserta didik untuk mengembangkan potensi diri melalui kegiatan yang menimbulkan apresiasi terhadap keragaman kebudayaan nusantara maupun manca negara (Ambarwangi, 2013, p. 82).

Pendidikan seni musik tidak dapat dipisahkan dengan kebudayaan yang ada di sekitarnya karena budaya yang ada di sekitar masyarakat menjadi bahan ajar. Sekolah musik, kursus musik maupun gereja yang mengadopsi ilmu musik Barat perlu mempelajari perkembangan konteks musik terutama perubahan-perubahan kondisi budaya, sosial maupun politik di Eropa karena musik Barat merupakan musik yang berkembang di Eropa dan mewakili kebudayaan yang berkembang di Eropa. Musik Barat disebarluaskan hingga sampai ke Indonesia dan mempengaruhi perkembangan musik yang ada di Indonesia. Musik-musik populer bahkan lagu-lagu perjuangan di Indonesia banyak menerapkan teori musik yang digunakan pada musik Barat. Konsep melodi, harmoni, dan bentuk lagu yang banyak ditemukan dalam lagu populer mengadopsi bentuk-bentuk yang dipakai dalam musik Barat. Pelaku pendidikan diharapkan melakukan penyelidikan yang seksama mengenai perkembangan musik Barat dengan tujuan membantu pengembangan potensi diri untuk mengapresiasikan, mengekspresikan bahkan mengkreasikan musik Barat. 
Indonesia sebagai pemilik banyak kebudayaan perlu menggali kebudayaan yang dimiliki. Indonesia yang memiliki lebih dari 1000 suku bangsa pastinya memiliki banyak kesenian yang dapat digarap. Beberapa kelompok masyarakat dapat saja mengagumi keindahan musik yang menerapkan teori-teori musik Barat, baik itu musik klasik maupun musik populer yang berkembang. Namun masyarakat di Indonesia juga perlu melihat keseniannya sendiri yang mewakili budayanya. Masyarakat di Indonesia perlu disadarkan bahkan ditanamkan rasa kagum akan musik-musik yang lahir dari kebudayaannya maka dari itu perlu digiatkan untuk mempelajari musik-musik lokal yang dimilikinya.

Pendidikan seni dilaksanakan dalam rangka membantu manusia mengungkapkan/ mengekspresikan kondisi yang ada di sekitarnya. Kegiatan pendidikan seni musik di Indonesia perlu memberikan esensi yang baru sehingga diharapkan menjadi sarana yang tepat bagi masyarakat untuk mengungkapkan kebudayaannya sendiri. Mempelajari kesenian musik lokal bukanlah kegiatan yang sia-sia karena pendidikan seni akan menolong manusia untuk mengenali, mempelajari, mengembangkan, dan melestarikan kebudayaan (Kristanto, 2017, p. 120). Pendidikan seni musik yang menggunakan kesenian lokal sebagai bahan ajarnya akan memaksimalkan peran pendidikan seni sebagai upaya konservasi budaya.

Kurikulum pendidikan seni perlu memberikan porsi yang cukup terhadap keseniankesenian lokal. Pendidikan seni musik berbasis bahan ajar multikultural akan memberikan ruang kepada budaya-budaya yang ada di Indonesia sebagai bahan ajar peserta didik. Pendidikan seni musik berbasis bahan ajar multikultural perlu dilaksanakan dalam rangka menunjukkan indentitas yang perlu dimiliki bangsa Indonesia. Kepemilikian indentitas yang kuat oleh bangsa akan membuat bangsa Indonesia mampu menanggulangi pengakuan kebudayaannya dari negara lain. Lembaga pendidikan baik formal, nonformal maupun informal perlu bekerja sama agar pendidikan seni musik berbasis bahan ajar multikultural dapat difungsikan secara maksimal.

Pembelajaran seni erat kaitannya dengan aktivitas ekspresi, kreasi, dan apresiasi. Lembaga pendidikan dapat melaksanakan ketiga aktivitas tersebut ketika melaksanakan pendidikan seni. Sekolah mewakili lembaga formal memiliki panduan yang jelas mengenai pelaksanaan pendidikan seni musik melalui kurikulum. Langkah konkret yang dapat dilakukan sekolah dalam rangka melaksanakan pendidikan seni musik berbasis bahan ajar multikultural adalah dengan memasukkan lagu daerah sebagai konten pembelajaran. Guru mengajar siswa untuk mempelajari dan membunyikan notasi yang digunakan dalam lagu 
daerah yang dipilih sebagai bentuk kegiatan ekspresi. Kegiatan kreasi dilakukan dengan cara menyajikan lagu daerah secara berbeda, dapat dengan vokal grup maupun penggunaan alat musik sehingga menghasilkan kesan yang berbeda.

Kegiatan apresiasi dilakukan cara mencari nilai-nilai yang ada pada karya seni melalui lirik yang dinyanyikan. Kegiatan apresiasi juga dapat dilakukan dengan cara memberikan penghargaan kepada penyajian karya sehingga secara tidak langsung menanamkan rasa menghargai terhadap keragaman. Sekolah tidak hanya mengajarkan lagu daerah sesuai dengan domisili sekolahnya, namun juga dapat mengajarkan lagu daerah yang berasal dari daerah lain. Kegiatan ekspresi, apresiasi dan kreasi ini membuat siswa merasa memiliki kebudayaannya dan guru dapat mengajar siswa untuk berusaha memelihara, mengembangkan, dan melestarikan budayanya sendiri (Rahmaniar \& Mardi, 2019, p. 47). Proses pembelajaran tersebut sesuai jika memposisikan multikultural sebagai bahan ajar dikarenakan pelaksanaan pendidikannya mendukung peserta didik untuk mengapresiasi kesenian dari kebudayaan lain sehingga peserta didik dapat mengenal dan menghargai keanekaragaman budaya musik yang ada di Indonesia.

Lembaga pendidikan nonformal diharapkan juga turut berperan aktif dalam melaksanakan pendidikan seni musik. Pembelajaran kesenian musik lokal akan lebih maksimal ketika dijalankan oleh masyarakat pemilik kebudayaan lokalnya baik melalui sanggar maupun komunitas yang ada. Masyarakat lokal memiliki keunggulan lebih berkaitan dengan penguasaan kebudayaan yang dimiliki. Penguasaan yang mendalam mengenai kesenian musik lokal akan mempermudah masyarakat melakukan transfer kebudayaan. Sanggar dan komunitas menolong masyarakat lokal untuk memainkan/ menyanyikan kesenian musik daerah sebagai kegiatan ekspresinya. Sanggar dan komunitas juga dapat melakukan kegiatan apresiasi dengan mengkaji kesenian lokal daerahnya sendiri. Proses transfer nilai yang ada dalam kebudayaan juga mudah dilakukan karena masyarakat lebih memahami konteks kebudayaannya. Pengkajian kesenian musik dari daerah lain juga dapat dilakukan sebagai kegiatan apresiasi yang dapat memunculkan ide bagi masyarakat lokal untuk membuat kreasi baru pada kesenian musiknya. Proses ini akan membantu masyarakat lokal untuk menjaga dan mengembangkan kesenian musiknya serta melakukan proses regenerasi.

Pendidikan seni musik berbasis bahan ajar multikultural perlu dilaksanakan bukan hanya sebagai pengekspresian kebudayaan lokal yang dimiliki oleh masyarakat tertentu. Pendidikan seni berbasis multikultural perlu melaksanakan kegiatan apresiasi baik 
mengapresiasi kebudayaannya sendiri maupun diluar kebudayaannya, demi mengajarkan toleransi dan sikap menghargai kebudayaan yang dimiliki oleh orang/ kelompok lain. Proses apresiasi yang baik dapat membuat masyarakat untuk mengkritisi kebudayaannya sehingga dapat memunculkan ide mengenai bagaimana menjaga bahkan mengkreasikan kebudayaannya. Kemampuan yang baik dalam menghargai kebudayaan orang lain akan membuat masyarakat di Indonesia mampu menjaga keanekaragaman budaya di Indonesia.

\section{Kesimpulan}

Pendidikan seni berbasis bahan ajar multikultural perlu dilaksanakan di Indonesia dalam rangka mengenalkan budaya lokal dan menanamkan sikap menghargai budayabudaya di Indonesia. Kemampuan untuk mengenal dan menghargai kebudayaan akan membuat masyarakat yang bersangkutan dapat menjaga keanekaragaman dan pluralitas yang dimiliki oleh masyarakat Indonesia. Pendidikan seni musik berbasis bahan ajar multikultural perlu didukung oleh semua lembaga pendidikan baik itu formal maupun nonformal. Peran aktif dari lembaga pendidikan di Indonesia diharapkan akan membantu proses regenerasi dan konservasi budaya.

\section{Kepustakaan}

Ambarwangi, S. (2013). Pendidikan Multikultural di Sekolah melalui Pendidikan Seni Tradisi. HARMONIA - Jurnal Pengetahuan Dan Pemikiran Seni, 13(1), 78-85. https://doi.org/10.15294/harmonia.v13i1.2535

Amirin, T. M. (2012). Implementasi Pendekatan Pendidikan Multikultural Kontekstual Berbasis Kearifan Lokal di Indonesia. Jurnal Pembangunan Pendidikan: Fondasi Dan Aplikasi, 1(1), 1-16.

Baidhawy, Z. (2005). Pendidikan Agama Berwawasan Multikultural. Jakarta: Erlangga.

Bank, J. A. (2002). An Introduction to Multicultural Education. Boston: Allyn and Bacon.

Desyandri. (2014). Peran Seni Musik dalam Pendidikan Multikultural. Jurnal Pembangunan Pendidikan: Fondasi Dan Aplikasi, 2(1), 1-12.

Dewantara, K. H. (2011). Karya Ki Hajar Dewantara Bagian Pertama Pendidikan (Keempat). Yogyakarta: Yayasan Persatuan Tamansiswa.

Hanafy, M. S. (2015). Pendidikan Multikultural dan Dinamika Ruang Kebangsaan. Jurnal Diskursus Islam, 3(1), 119-139. Retrieved from http://journal.uinalauddin.ac.id/index.php/diskursus_islam/article/view/198

Irawan, D. (Ed.). (2017). Paradigma Pendidikan Seni. Yogyakarta: Thafa Media. Koentjaraningrat. (2015). Pengantar Ilmu Antropologi. Jakarta: Rineka Cipta. 
Kristanto, A. (2017). Memahami paradigma pendidikan seni. ABDIEL, 119-126.

Muslim. (2016). Nilai-Nilai Pendidikan Multikultural dalam Buku Teks Bahasa Indonesia untuk Siswa SMP. Riksa Bahasa, 2(1), 55-66.

Rahmaniar, R., \& Mardi, M. (2019). Ideologi Konservatisme Dalam Pendidikan Seni Musik. Tonika: Jurnal Penelitian Dan Pengkajian Seni, 2(2), 38-48. https://doi.org/10.37368/tonika.v2i2.108

Retnowati. (n.d.). Pendidikan Seni Musik di SD. Retrieved June 10, 2019, from https://www.kompasiana.com/retno88/55006190a333119f6f510d22 $\%$ 5B01/pendidikan-seni-musik-di-sd

Safrina, R. (2002). Pendidikan Seni Musik. Bandung: CV. Maulana.

Triyanto. (2016). Paradigma Humanistik dalam Pendidikan Seni. Imajinasi, X(1), 1-10.

Wibawa, A. P. (2017). Paradigma Pendidikan Seni di Era Globalisasi Berbasis Wacana. DHARMASMRTI, XVI(1), 48-56. Retrieved from https://media.neliti.com/media/publications/266338-paradigma-pendidikan-seni-diera-globali-c4af3bbf.pdf

Zamroni. (2011). Pendidikan Demokrasi pada Masyarakat Multikultural. Yogyakarta: Gavin Kalam Utama. 